\title{
Article \\ Characterization and Biotechnological Potential of Extracellular Polysaccharides Synthesized by Alteromonas Strains Isolated from French Polynesia Marine Environments
}

\author{
Patrícia Concórdio-Reis ${ }^{1,2}$, Vítor D. Alves ${ }^{3} \mathbb{D}$, Xavier Moppert ${ }^{4}$, Jean Guézennec ${ }^{5}$, Filomena Freitas ${ }^{1,2, * \mathbb{D}}$ \\ and Maria A. M. Reis ${ }^{1,2} \mathbb{D}$ \\ check for \\ 1 Associate Laboratory i4HB-Institute for Health and Bioeconomy, School of Science and Technology, \\ NOVA University Lisbon, 2829-516 Caparica, Portugal; pc.reis@campus.fct.unl.pt (P.C.-R.); \\ amr@fct.unl.pt (M.A.M.R.) \\ 2 UCIBIO-Applied Molecular Biosciences Unit, Department of Chemistry, School of Science and Technology, \\ NOVA University Lisbon, 2829-516 Caparica, Portugal \\ 3 LEAF-Linking Landscape, Environment, Agriculture and Food-Research Center, Instituto Superior de \\ Agronomia, Universidade de Lisboa, 1349-017 Lisbon, Portugal; vitoralves@isa.ulisboa.pt \\ 4 Pacific Biotech SAS, BP 140 289, 98701 Arue, Tahiti, French Polynesia; xmoppert@pacific-biotech.pf \\ 5 AiMB (Advices in Marine Biotechnology), 17 Rue d'Ouessant, 29280 Plouzané, France; \\ guezennec.jean@wanadoo.fr \\ * Correspondence: a4406@fct.unl.pt; Tel.: +351-212-948-357
} updates

Citation: Concórdio-Reis, P.; Alves, V.D.; Moppert, X.; Guézennec, J.;

Freitas, F; Reis, M.A.M.

Characterization and

Biotechnological Potential of

Extracellular Polysaccharides

Synthesized by Alteromonas Strains

Isolated from French Polynesia

Marine Environments. Mar. Drugs

2021, 19, 522. https://doi.org/

$10.3390 /$ md19090522

Academic Editor: Maria

Michela Corsaro

Received: 3 September 2021

Accepted: 14 September 2021

Published: 17 September 2021

Publisher's Note: MDPI stays neutral with regard to jurisdictional claims in published maps and institutional affiliations.

Copyright: (c) 2021 by the authors. Licensee MDPI, Basel, Switzerland. This article is an open access article distributed under the terms and conditions of the Creative Commons Attribution (CC BY) license (https:// creativecommons.org/licenses/by/ $4.0 /)$.

\begin{abstract}
Marine environments comprise almost three quarters of Earth's surface, representing the largest ecosystem of our planet. The vast ecological and metabolic diversity found in marine microorganisms suggest that these marine resources have a huge potential as sources of novel commercially appealing biomolecules, such as exopolysaccharides (EPS). Six Alteromonas strains from different marine environments in French Polynesia atolls were selected for EPS extraction. All the EPS were heteropolysaccharides composed of different monomers, including neutral monosaccharides (glucose, galactose, and mannose, rhamnose and fucose), and uronic acids (glucuronic acid and galacturonic acid), which accounted for up to $45.5 \mathrm{~mol} \%$ of the EPS compositions. Non-carbohydrate substituents, such as acetyl (0.5-2.1 wt\%), pyruvyl (0.2-4.9 wt\%), succinyl (1-1.8 wt \%), and sulfate (1.98-3.43 wt \%); and few peptides (1.72-6.77 wt\%) were also detected. Thermal analysis demonstrated that the EPS had a degradation temperature above $260{ }^{\circ} \mathrm{C}$, and high char yields (32-53\%). Studies on EPS functional properties revealed that they produce viscous aqueous solutions with a shear thinning behavior and could form strong gels in two distinct ways: by the addition of $\mathrm{Fe}^{2+}$, or in the presence of $\mathrm{Mg}^{2+}, \mathrm{Cu}^{2+}$, or $\mathrm{Ca}^{2+}$ under alkaline conditions. Thus, these EPS could be versatile materials for different applications.
\end{abstract}

Keywords: Alteromonas sp.; exopolysaccharide characterization; functional properties; rheology; gelation

\section{Introduction}

Sea water covers more than $70 \%$ of the earth's surface and represents the largest ecosystem of the planet. Despite the enormous metabolic diversity and discovery potential, marine natural resources are still underexplored, understudied, and underutilized in biotechnology [1,2]. From the shallow coastal waters to the deep ocean, marine habitats have a variety of unique ecological characteristics that prompted marine microbial communities to develop adaptation mechanisms in order to survive [2,3]. This is especially true in extreme environments such as those found in deep-sea, hydrothermal vents, volcanic and hydrothermal marine areas, marine salterns, and sea ice in polar regions [4].

Important molecules for cell survival are extracellular polysaccharides (EPS), high molecular weight carbohydrate polymers secreted by many microorganisms, particularly bacteria $[5,6]$. Bacterial EPS make up a substantial part of the extracellular polymers that 
surround cells in microbial communities [7]. A variety of functions have been attributed to EPS, including adhesion to surfaces, cell-cell recognition and aggregation, entrapment of nutrients, and protective barrier [8-10]. EPS are especially important for marine bacteria to thrive under the extreme conditions characteristic of their environment, such as high pressure, high salinity, low nutrient concentration, low or high temperature, and heavy metal presence [11]. Moreover, bacterially synthesized EPS are commercially appealing due to their interesting physicochemical and functional properties, with potential applicability as biomaterials, rheology modifiers of aqueous solutions, or bioactive therapeutic agents $[10,12]$. In fact, marine bacteria are currently a very promising source for the discovery of EPS with distinctive structures and unique properties, with applicability in several industrial sectors $[1,13]$. These EPS often exhibit a high diversity in structure and composition, that might include rare sugars, such as fucose or rhamnose $[13,14]$, which are known to confer the biopolymers' biological activity [12]. High content in uronic acids and sulfate groups are also found within marine bacteria derived EPS, which further contributes to their unique properties [13].

In the course of discovery of biomolecules of biotechnological interest, it is well accepted that microorganisms originating from unusual environments, such as deep-sea hydrothermal vents, Antarctica, and microbial mats located in some Polynesian atolls, will provide a valuable source for novel biopolymers, including EPS with unique properties [1,15]. Microbial mats (locally called "Kopara" mats) are characterized by salt concentrations ranging from 5 to $42 \mathrm{~g} \mathrm{~L}^{-1}, \mathrm{pH}$ values between 6 to 10.5, and temperatures ranging from $20{ }^{\circ} \mathrm{C}$ during the night, up to $42{ }^{\circ} \mathrm{C}$ [16]. To date, only five genera of EPS-producing bacteria were found in such environments, i.e., Pseudomonas, Pseudoalteromonas, Alteromonas, Paracoccus, and Vibrio, with uronic acids and amino-sugars content up to $50 \%(w / w)$, as well as acyl and sulfate groups, in their secreted EPS composition, which render them unique properties and great potential for use in several applications, including in the cosmetic, biomedicine, pharmaceutical, and therapeutics fields [16].

In this study, six Alteromonas strains originating from different locations in French Polynesia were screened for EPS production in an aerobic, carbohydrate-based medium. The resulting EPS were characterized in terms of chemical composition, molecular mass distribution, and thermal properties. To investigate their potential as biomaterials in important biotechnological applications, the functional properties of the biopolymers were assessed, including determination of their rheological properties and gel forming capacity.

\section{Results and Discussion}

\subsection{Isolation and Identification of EPS Producing Strains}

The six Alteromonas isolates used in this study were selected based on their ability to show a mucoid phenotype (Figure 1). Strains Mo 169, Mo 278, and Mo 203 were originally isolated from a giant clam, a sea anemone, and a "Kopara" mat sample, respectively, collected at Moorea Island lagoon (Society Archipelago). Strains Fak 1576 and Fak 1386 were isolated from a coral and a pearl oyster mantle, respectively, at the Fakarava atoll, while strain Tik 650 was isolated from a "Kopara" mat sample collected at Tikehau atoll (Table 1). Upon taxonomical analysis, the strains were identified as belonging to the Alteromonas macleodii specie, except for strain Tik 650 identified as a Alteromonas simiduii.

\subsection{EPS Characterization}

\subsubsection{Chemical Composition}

The Alteromonas EPS were heteropolysaccharides composed of different monomers, including neutral monosaccharides (glucose, galactose, and mannose, rhamnose, and fucose) and uronic acids (glucuronic acid and galacturonic acid) (Table 2).

Almost all biopolymers were rich EPS in uronic acids, with glucuronic acid (GlcA) and galacturonic acid (GalA) accounting for up to $45.5 \mathrm{~mol} \%$. Such high contents in uronic acids were also reported for EPS produced by deep-sea hydrothermal bacterium A. infernus GY 785 [17], and Alteromonas sp. JL2810 collected from surface seawater [11]. Due to the 
uronic acids in their composition, both Alteromonas strains showed a high metal binding capacity, leading to a possible use in wastewater treatment and metal recovery [11,18]. On the other hand, no uronic sugars were detected in the EPS produced by A. hispanica F32 isolated from a hypersaline environment [19] and two strains of $A$. stellipolaris, namely, strains PQQ-42 and PQQ-44, isolated from a fish hatchery [20].

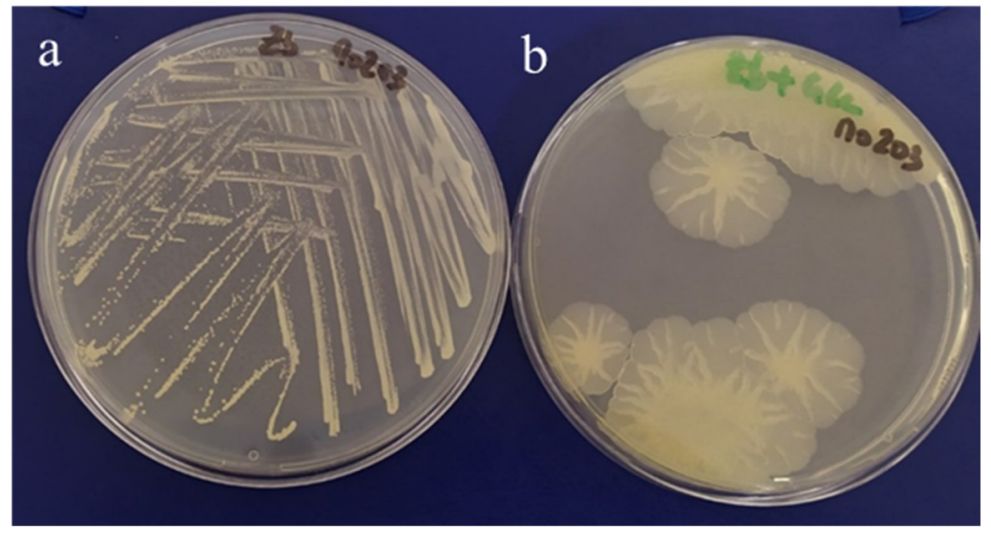

Figure 1. Culture of strain Mo 203 on Zobell-agar medium (a) and glucose-supplemented $\left(30 \mathrm{~g} \mathrm{~L}^{-1}\right)$ Zobell-agar medium (b).

Table 1. Isolates' identification, sampling location and sample source of the EPS producing Alteromonas strains isolated from marine environments in French Polynesia.

\begin{tabular}{ccccc}
\hline EPS & $\begin{array}{c}\text { Isolate Strain } \\
\text { Designation }\end{array}$ & Sampling Site & Sample Source & Accession Number \\
\hline A & Mo 169 & Moorea Island lagoon & Giant clam (Tridacna maxima) & CNCM I-5374 \\
B & Mo 278 & Moorea Island lagoon & Sea Anemone (Actiniaria) & CNCM I-5375 \\
C & Fak 1576 & Fakarava atoll & Coral & CNCM I-5376 \\
D & Tik 650 & Tikehau atoll & "Kopara" mat & CNCM I-5523 \\
E & Fak 1386 & Fakarava atoll & Pearl oyster mantle & CNCM I-5524 \\
F & Mo 203 & Moorea Island lagoon & "Kopara" mat & CNCM I-3970 \\
\hline
\end{tabular}

Table 2. Characterization of EPS produced by Alteromonas strains isolated from French Polynesia: monosaccharide (Fuc, fucose; Gal, galactose; GalA, galacturonic acid; Glc, glucose; GluA, glucuronic acid; Man, mannose; and Rha, rhamnose) and acyl groups (Ac, acetate; Pyr, pyruvate; and Suc, succinate) composition; sulfate, uronic acids, protein, and inorganic salts content; average molecular weight (Mw); polydispersity index (PDI); and thermal degradation temperature (Tdeg).

\begin{tabular}{|c|c|c|c|c|c|c|c|c|}
\hline EPS & $\begin{array}{c}\text { Monosaccharide Composition } \\
\text { (Molar Ratio) }\end{array}$ & $\begin{array}{l}\text { Acyl Groups } \\
(\mathbf{w t} \%)\end{array}$ & $\begin{array}{l}\text { Sulfate } \\
(w t \%)\end{array}$ & $\begin{array}{l}\text { Protein } \\
(w t \%)\end{array}$ & $\begin{array}{c}\text { Inorganic } \\
\text { Content } \\
(w t \%)\end{array}$ & $\begin{array}{c}\mathrm{M}_{\mathrm{w}} \\
(\mathrm{MDa})\end{array}$ & PDI & $\begin{array}{l}\mathrm{T}_{\mathrm{deg}} \\
\left({ }^{\circ} \mathrm{C}\right)\end{array}$ \\
\hline A & $\begin{array}{l}\text { Glc:GlcA:Man:Gal:GalA } \\
(2.5: 2.5: 1.5: 1.5: 1.5)\end{array}$ & $\begin{array}{l}\text { Ac }(0.5 \pm 0.1) \\
\text { Pyr }(4.9 \pm 0.1)\end{array}$ & $2.8 \pm 0.1$ & $2.8 \pm 0.4$ & $7.7 \pm 1.5$ & $\begin{array}{c}1.6 \\
4.6^{1}\end{array}$ & $\begin{array}{c}1.3 \\
1.3^{1}\end{array}$ & 269 \\
\hline B & $\begin{array}{l}\text { Gal:GlcA:Glc:GalA } \\
(2: 1.5: 1: 1)\end{array}$ & $\begin{array}{l}\text { Ac }(0.5 \pm 0.0) \\
\text { Pyr }(0.2 \pm 0.0) \\
\text { Suc }(1.8 \pm 0.1)\end{array}$ & $3.3 \pm 0.3$ & $3.5 \pm 0.1$ & $20.0 \pm 1.7$ & 4.6 & 1.4 & 265 \\
\hline C & $\begin{array}{c}\text { Gal:Rha:Man:Glc:GlcA:GalA:Fuc } \\
\text { (4.5:2:1.5:1:1:1:0.5) }\end{array}$ & $\operatorname{Pyr}(1.1 \pm 0.2)$ & $3.4 \pm 0.0$ & $2.6 \pm 1.0$ & $34.7 \pm 0.2$ & 1.2 & 1.4 & 268 \\
\hline $\mathrm{D}$ & $\begin{array}{c}\text { GlcA:Glc:Gal:Man:GalA } \\
(3: 2: 2: 1.5: 1.5)\end{array}$ & Ac $(2.1 \pm 0.0)$ & $2.0 \pm 0.0$ & $6.8 \pm 0.2$ & $11.4 \pm 0.3$ & 1.4 & 1.5 & 262 \\
\hline $\mathrm{E}$ & $\begin{array}{c}\text { Gal:Man:Rha:Glc:GlcA:GalA } \\
(3: 2: 1: 1: 1: 1)\end{array}$ & Suc $(1.0 \pm 0.0)$ & $2.9 \pm 0.0$ & $2.1 \pm 0.3$ & $15.0 \pm 0.1$ & $\begin{array}{c}2.5 \\
4.3^{1}\end{array}$ & $\begin{array}{c}1.1 \\
1.5^{1}\end{array}$ & 267 \\
\hline F & $\begin{array}{c}\text { Glc:Gal:GlcA:Rha:GalA } \\
(2: 2: 2: 1: 1)\end{array}$ & $\begin{array}{l}\text { Ac }(0.7 \pm 0.0) \\
\text { Pyr }(5.5 \pm 0.3)\end{array}$ & $3.4 \pm 0.0$ & $1.7 \pm 0.0$ & $13.7 \pm 0.3$ & 3.2 & 1.2 & 260 \\
\hline
\end{tabular}

${ }^{1}$ EPS presented two distinct peaks in the size exclusion chromatography plots. 
The rare sugar rhamnose (Rha) was also present in significant proportions in EPS C, E, and F. Although rhamnose was previously reported in EPS from Alteromonas strains [11,17,19-21], only a few exhibited significant amounts of this sugar in their composition. Examples include the EPS produced by A. macleodii subsp. fijiensis biovar deepsane HYD 657 [21], and the EPS from Alteromonas sp. JL2810 that consisted in a trisaccharide repeating unit composed of Rha, GalA, and mannose (Man) [11]. EPS C also contained fucose (Fuc) in its composition, although at low quantities. The presence of rare sugars, such as Rha and Fuc, or uronic acids makes these EPS excellent candidates for various applications, such as anti-inflammatory and antioxidant agents, or in the synthesis of nucleoside analogs used as antiviral substances [22]. Moreover, these EPS can be used as sources of rare sugar monosaccharides with high value applications. For instance, rhamnose is used as precursor in the synthesis of aroma and flavors [22], whereas fucose is often present in the composition of anticarcinogenic and anti-inflammatory drugs, and incorporated in skin care formulations for the acceleration of wound healing [22].

Non-sugar substituents, such as acetyl, pyruvyl, succinyl, and sulfate, were determined in the Alteromonas EPS (Table 2). All the six EPS had at least one type of acyl substituent with a total acyl content accounting for 1 to $5.5 \%$ of the EPS dry mass. EPS $\mathrm{A}$ and $\mathrm{F}$ were particularly rich in pyruvyl groups (4.9-5.5 wt $\%$ ) while EPS E and B exhibited a higher content in succinyl substituents (1 and $1.8 \mathrm{wt} \%$, respectively). EPS D only had acetyl groups, which accounted for $2.1 \mathrm{wt} \%$ of the EPS' mass. Acetyl and pyruvyl substituents, although rarely, have been reported in a few EPS produced by Alteromonas strains $[19,21]$. On the other hand, succinyl, to the best of our knowledge, has never been found in Alteromonas EPS. Additionally, sulfate substituents were found in all EPS, but in low concentrations, ranging from 2.0-3.4 wt\% (Table 2). Although more commonly found in algae, sulfated EPS have been described to be produced by some marine bacteria [2], including A. hispanica F32 (0.25 wt\%) [19], A. infernus GY785 (3 wt\%) [17], and Alteromonas HYD $657(7.5 \mathrm{wt} \%)$ [21]. Sulfated polysaccharides are of great interest in the fields of biomedicine, pharmaceuticals, nutraceutical foods, and cosmetics due to their biological activity [2]. Reported bioactive properties include anti-inflammatory, immunomodulatory, antioxidant, antiviral, antibacterial, antiulcer, antitumor and antihyperlipidaemic activity, as well as anti-coagulant and/or anti-thrombotic properties [23-26]. In fact, Sahana and Rekha [13] recently reported that the EPS produced by Alteromonas HYD 657 was biocompatible, capable of promoting cell proliferation, and contributed to wound healing in vitro.

After the purification process, the EPS samples presented some content of protein and inorganic salts (Table 2). The presence of a residual protein content (1.7-6.8 $\mathrm{wt} \%)$ in the EPS was previously reported for EPS produced by other Alteromonas strains (0-8 wt \%) $[13,19,21,27]$. The inorganic salts content of EPS B, C, and E (15.0-34.7 wt\%) was similar to those reported (15.5-40 wt\%) for A. hispanica F32 [19] and Alteromonas sp. PRIM-28 [13], whereas EPS A, $\mathrm{D}$, and $\mathrm{F}$ had a comparatively lower content (7.7-13.7 wt \%).

\subsubsection{Fourier Transform Infra-Red (FTIR) Spectroscopy}

The FTIR spectra of the EPS, presented in Figure 2, contained bands typically found in carbohydrates. The broad and intense band observed in the frequency range of $3500-3000 \mathrm{~cm}^{-1}$ corresponded to the $\mathrm{O}-\mathrm{H}$ stretching vibration of hydroxyl groups, which partially overlaps the $\mathrm{C}-\mathrm{H}$ stretching peak of $\mathrm{CH}_{2}$ groups that appeared at around $2930 \mathrm{~cm}^{-1}[28,29]$. The absorption peak at approximately $1600 \mathrm{~cm}^{-1}$ and the adsorption region between 1300 and $1450 \mathrm{~cm}^{-1}$ are characteristic of the $\mathrm{C}=\mathrm{O}$ asymmetric and symmetric stretching vibrations, respectively, of the carboxylates from the uronic acids [28-30]. The band found at around $1245 \mathrm{~cm}^{-1}$ can be attributed to the stretching vibration of C-O-C from acyls, and/or of $\mathrm{S}=\mathrm{O}$ from sulphate groups $[28,30,31]$. Finally, the bands in the frequency range of $1200-900 \mathrm{~cm}^{-1}$ can be assigned to C-O and C-C vibrations of the glycosidic bonds and pyranose carbohydrate ring $[28,30]$. 


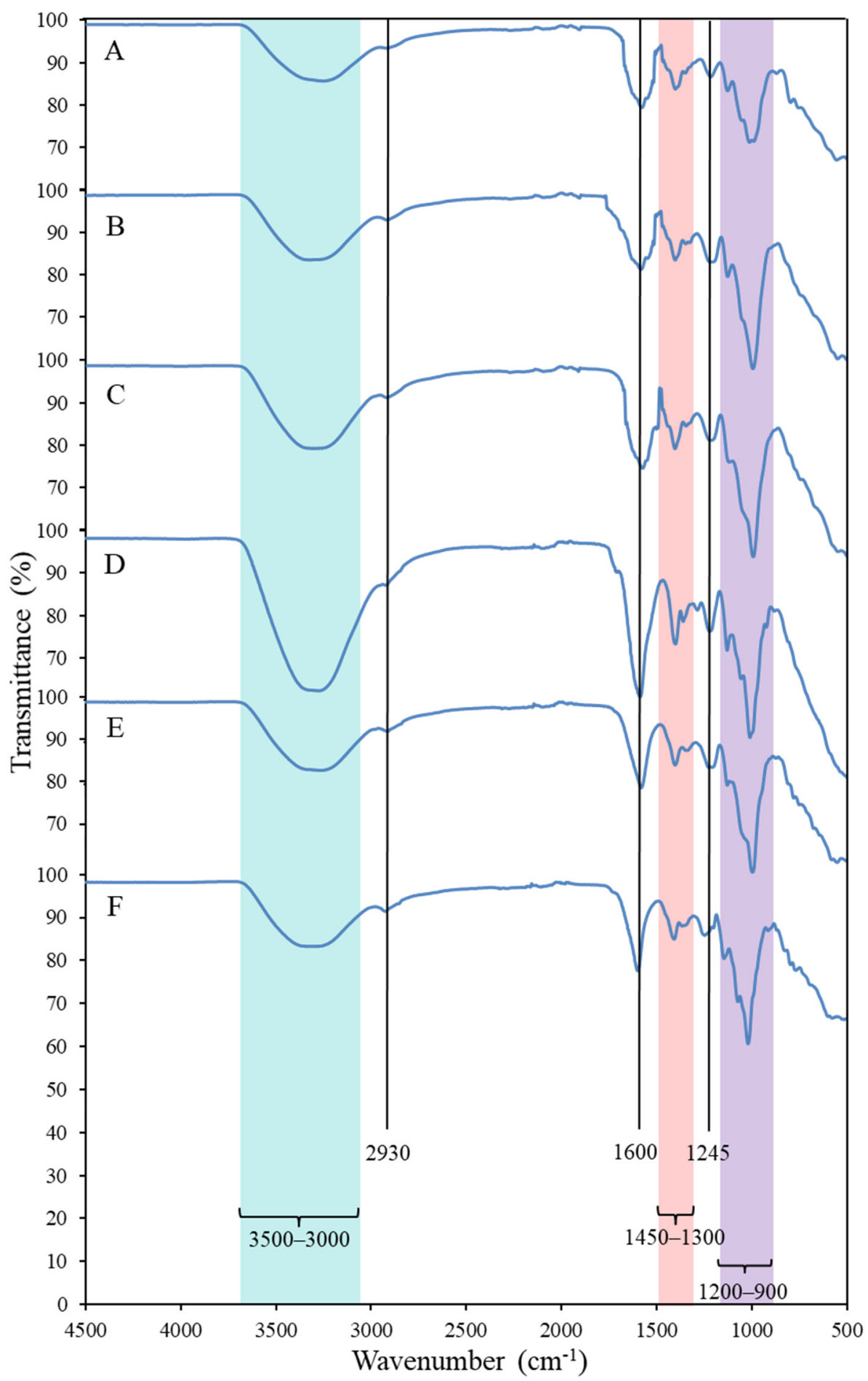

Figure 2. FTIR spectra of EPS A-F produced by Alteromonas strains isolated from French Polynesia.

\subsubsection{Molecular Mass Distribution}

EPS characterization in terms of composition and average molecular weight is presented in Table 2. Regarding the average molecular weights $\left(\mathrm{M}_{\mathrm{w}}\right)$, all the EPS produced by Alteromonas strains presented a high Mw value, ranging from 1.2-4.6 MDa (Table 2). These $\mathrm{Mw}$ values are within the ranges reported for commercial EPS, such as xanthan, alginate, and hyaluronic acid (0.3-50 MDa) [12], and for other Alteromonas EPS (1.1-2 MDa), such as those produced by Alteromonas infernus GY785 [17], A. macleodii subsp. fijiensis HYD 657 [21], and A. macleodii subsp. fijiensis biovar medioatlantica [27]. However, these values 
were higher than the Mw estimated for the EPS obtained from Alteromonas sp. PRIM-28 [13] and Alteromonas sp. JL2810 [11], which were $780 \mathrm{kDa}$ and $0.17 \mathrm{MDa}$, respectively, and lower than 19.7 MDa, the highest Mw reported so far for Alteromonas EPS [19]. Interestingly, two distinct chromatographic peaks were detected in EPS A and EPS E, suggesting that strains Mo 169 and Fak 1386 might synthesize two types of high molecular weight EPS. Examples of the two distinctive HPSEC results, one and two chromatographic peaks, are presented in Appendix A (Figure A1). All EPS presented low PDI values, thus indicating their homogeneity in terms of molecules chain length (Table 2).

\subsubsection{Thermogravimetric Analysis}

The applicability of materials is also dependent on their thermal characteristics; thus, the thermal stability of the six EPS was studied using thermogravimetric analysis (TGA) (Figure 3). The thermal degradation of all the EPS occurred in three phases. In the first phase, an increase in temperature from $37-45^{\circ} \mathrm{C}$ to $173-193{ }^{\circ} \mathrm{C}$ resulted in a decrease in weight of 12.1-17.5\% (degradation steps are presented in Appendix B, Table A1), which was probably related to moisture loss [28,32]. The highest mass loss value $(17.5 \%)$ was observed for EPS E, which suggests a strong water binding capacity. Above this temperature, a significant weight loss of 30.2-45.1\% occurred until $386-429^{\circ} \mathrm{C}$ (Figure 3 and Table A1), which corresponded to the second degradation phase, probably related to the decomposition of the polysaccharide's side chains [28]. The EPS's thermal degradation temperature $\left(\mathrm{T}_{\mathrm{deg}}\right)$ was similar in all EPS, varying between $260{ }^{\circ} \mathrm{C}$ and $269^{\circ} \mathrm{C}$ (Table 2). Finally, as temperatures rose above $386-429^{\circ} \mathrm{C}$, a gradual decrease in mass was observed for all EPS (2.5-6.4\%), identified as the third step of thermal degradation (Figure 3), which is associated with polysaccharide's main-chain scission [28]. All the EPS showed high char yields (32-53\%), with EPS C and B presenting the highest results (53\% and $46 \%$, respectively). This trend is in agreement with previous results, as both EPS also presented the highest inorganic content in their composition (Table 2).

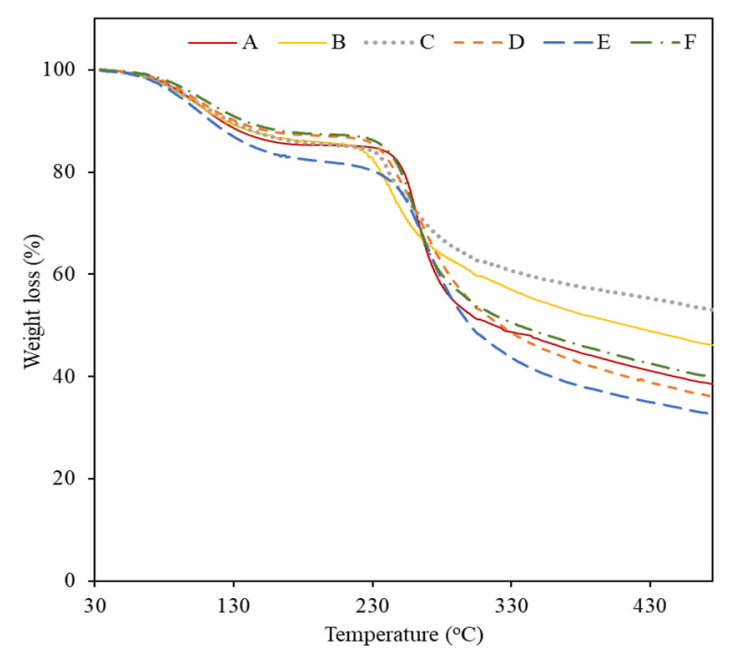

Figure 3. Thermogravimetric analysis (TGA) curves of EPS produced by Alteromonas strains isolated from French Polynesia.

\subsection{EPS Functional Properties}

Polysaccharides are excellent candidates for biomaterials with applications in several industries due to their valuable rheological properties, as well as the ability to form polymeric structures, such as films, gels, and emulsions [22].

\subsubsection{Rheological Properties}

The flow curves obtained for purified EPS solutions (1 $\mathrm{wt} \%$ ) are presented in Figure 4. It can be observed that the EPS have diverse thickening capacities, as they show dif- 
ferent values of apparent viscosity for the same shear rate, with the following order: $\mathrm{A}>\mathrm{E}>\mathrm{B} \sim \mathrm{C}>\mathrm{D}>\mathrm{F}$. This trend is clearly visible at the lower shear rate values tested, where the curves present or approach the first Newtonian plateau at which a high degree of polymer chains interactions (e.g., entanglements) is expected, and the molecules show high flow resistance and thereby higher viscosity $[33,34]$.

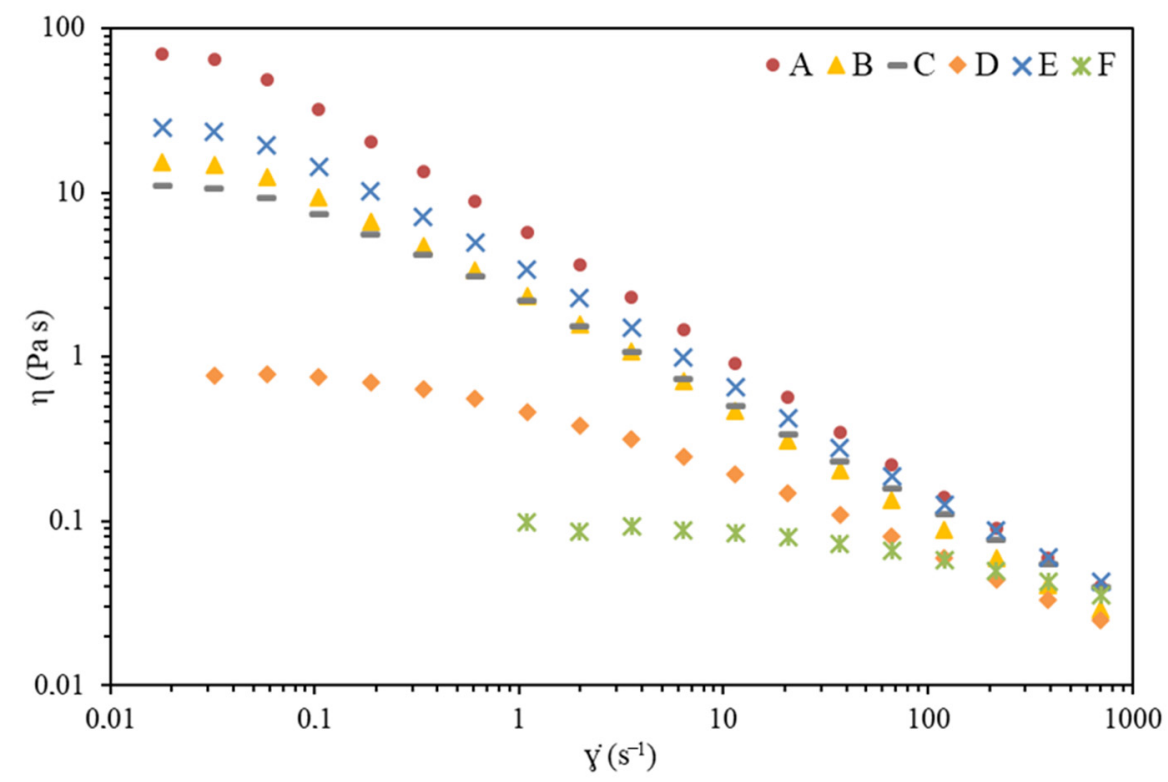

Figure 4. Apparent viscosity $(\eta)$ as a function of shear rate $(\dot{g})$ for different aqueous solutions $(1 \%$ $w / w)$ prepared with EPS produced by Alteromonas strains isolated from French Polynesia.

The Newtonian plateau at low shear rates followed by a shear thinning behavior observed for all Alteromonas sp. EPS solutions is in line to that reported for other polysaccharide aqueous solutions [33-37]. This viscosity dependence with the shear rate is commonly described by mathematical models, such as the Carreau model [38]:

$$
\eta=\eta_{\infty}+\frac{\eta_{0}+\eta_{\infty}}{\left[1+(\lambda \dot{\gamma})^{2}\right]^{\frac{1-n}{2}}}
$$

where $\eta$ is the apparent viscosity (Pa.s), $\dot{\gamma}$ is the shear rate $\left(\mathrm{s}^{-1}\right), \lambda$ is a time constant (s), $\eta_{0}$ (Pa.s) is the zero-shear rate viscosity (first Newtonian plateau), $\eta_{\infty}$ is the viscosity of the second Newtonian plateau (Pa.s), and $n$ is the viscosity exponent. Equation (1) was simplified assuming $\eta_{\infty}$ values much lower than $\eta_{0}$ and $\eta$, fitted to the data of Figure 4 and the estimated parameter values are presented in Table 3.

Table 3. Carreau model parameters estimated for different aqueous solutions $(1 \% w / w)$ prepared with EPS produced by Alteromonas strains isolated from French Polynesia.

\begin{tabular}{cccccc}
\hline EPS & $\boldsymbol{\eta}_{\mathbf{0}}$ (Pa.s) & $\boldsymbol{n} \mathbf{( - )}$ & $\boldsymbol{\lambda} \mathbf{( s )}$ & $\mathbf{r}^{\mathbf{2}}$ & $\mathbf{M R E}^{*} \mathbf{( \% )}$ \\
\hline A & $76.2 \pm 2.1$ & $0.181 \pm 0.051$ & $24.6 \pm 2.8$ & 0.999 & 13.6 \\
B & $16.1 \pm 0.3$ & $0.361 \pm 0.024$ & $19.7 \pm 1.5$ & 0.999 & 9.8 \\
C & $11.3 \pm 0.2$ & $0.437 \pm 0.021$ & $17.7 \pm 1.5$ & 0.999 & 14.9 \\
D & $0.74 \pm 0.02$ & $0.549 \pm 0.034$ & $2.26 \pm 0.27$ & 0.998 & 5.6 \\
E & $26.3 \pm 0.4$ & $0.338 \pm 0.025$ & $21.2 \pm 1.6$ & 0.999 & 5.9 \\
F & $0.09 \pm 0.01$ & $0.772 \pm 0.056$ & $0.07 \pm 0.04$ & 0.998 & 3.1 \\
\hline
\end{tabular}

*MRE $=\sum_{i=1}^{j}\left|\frac{\left(x_{\exp i-} x_{\text {model } i}\right)}{x_{\exp i}}\right| / j \times 100$. 
EPS A shows a higher thickening effect, with an estimated $\eta_{0}$ of $76.2 \pm 2.1$ Pa.s, followed by a quick transition to a strong shear thinning illustrated by the low viscosity exponent $(n=0.181 \pm 0.051)$. This behavior can be compared with that demonstrated by 1 wt.\% xanthan solution [37]. As the viscosity decreases, by the order indicated above, the time constant values also decrease. As the time constant is a relaxation time, it means that, under lower viscosity values, the rate of formation of new interactions between molecules increases over the rate of their disruption. Consequently, the transition from Newtonian plateau to shear-thinning regimes moves to higher shear rate values, as observed (Figure 4) [35,36]. Polysaccharides with shear thinning behavior are commercially relevant in specific areas such as cosmetics, food products, pharmaceuticals, oil drilling fluids, and paints [39].

An evident correlation is not detected between the viscosity properties and the average molecular weight and chemical composition of the EPS presented in Table 2. The interactions between polymer chains in solutions are strongly dependent, not only on such factors, but also on the on the polymers chemical structure. As such, deeper studies are needed to evaluate the effect of single factors (e.g., chemical composition and structure, average molecular weight, charge density, polymer concentration, temperature, and ionic strength) and their interaction on the observed apparent viscosity.

\subsubsection{Gel Forming Capacity}

The presence of negatively charged groups (uronic acids, sulfate, and acyl substituents) render EPS a polyelectrolyte character that allows the formation of physical cross-linking interactions with cations, leading to gel formation [2,40]. The EPS gelation ability was tested using different polyvalent cations $\left(\mathrm{Mg}^{2+}, \mathrm{Cu}^{2+}, \mathrm{Ca}^{2+} ; \mathrm{Fe}^{2+}\right.$, and $\left.\mathrm{Fe}^{3+}\right)$, under standard and alkaline conditions (Table 4). Gel formation was assessed according with their strength and homogeneity: $(+)$ for homogeneous gels that maintained their gel structure in an inversion test (Figure 5), (-) for homogeneous gels that did not sustain their structure in the inversion test, and (-) for small non-homogeneous gels. Images of gels (-) and (-) are presented in Appendix C (Figure A2). As shown in Table 4, under standard conditions, only EPS $\mathrm{C}$ and $\mathrm{E}$ were able to form strong homogenous gels with $\mathrm{Fe}^{2+}$ (Figure 5). Interestingly, both EPS were majorly composed of galactose (Gal) and, with the exception of Fuc in EPS $\mathrm{C}$, presented the same sugar monomers but in different ratios (Table 2). Moreover, both had the lowest uronic acid content (around 17 and $22 \mathrm{~mol} \%$, respectively) of the six EPS tested. $\mathrm{Cu}^{2+}$ and $\mathrm{Fe}^{3+}$ were capable of promoting gelation of EPS A and C; and A and D, respectively. Although homogenous, these gels were weaker, and did not maintain their structure upon inversion.

Table 4. Gel formation under standard and alkaline conditions was assessed according to their strength and homogeneity: (+) for homogeneous gels that maintained their gel structure in an inversion test, (-) for homogeneous gels that did not sustain their structure in the inversion test, (-) for small non-homogeneous gels, and blank for no gelation observed.

\begin{tabular}{|c|c|c|c|c|c|c|}
\hline \multicolumn{7}{|c|}{ Standard Conditions } \\
\hline Cation & A & B & $\mathrm{C}$ & D & E & $\mathbf{F}$ \\
\hline $\mathrm{Mg}^{2+}$ & & & & & & \\
\hline $\mathrm{Cu}^{2+}$ & - & & - & & - & \\
\hline $\mathrm{Ca}^{2+}$ & & & & & & \\
\hline $\mathrm{Fe}^{2+}$ & & & + & & + & \\
\hline $\mathrm{Fe}^{3+}$ & - & & & & - & - \\
\hline \multicolumn{7}{|c|}{ Alkaline conditions } \\
\hline Cation & A & B & $\mathrm{C}$ & D & $\mathbf{E}$ & $\mathbf{F}$ \\
\hline $\mathrm{Mg}^{2+}$ & + & - & - & - & - & + \\
\hline $\mathrm{Cu}^{2+}$ & & + & - & & - & \\
\hline
\end{tabular}


Table 4. Cont.

\begin{tabular}{ccccccc}
\hline \multicolumn{7}{c}{ Alkaline conditions } \\
\hline Cation & A & B & C & D & E & F \\
\hline $\mathrm{Ca}^{2+}$ & + & - & - & - & - & + \\
$\mathrm{Fe}^{2+}$ & - & - & - & - & - & - \\
$\mathrm{Fe}^{3+}$ & - & - & - & - & \\
\hline
\end{tabular}
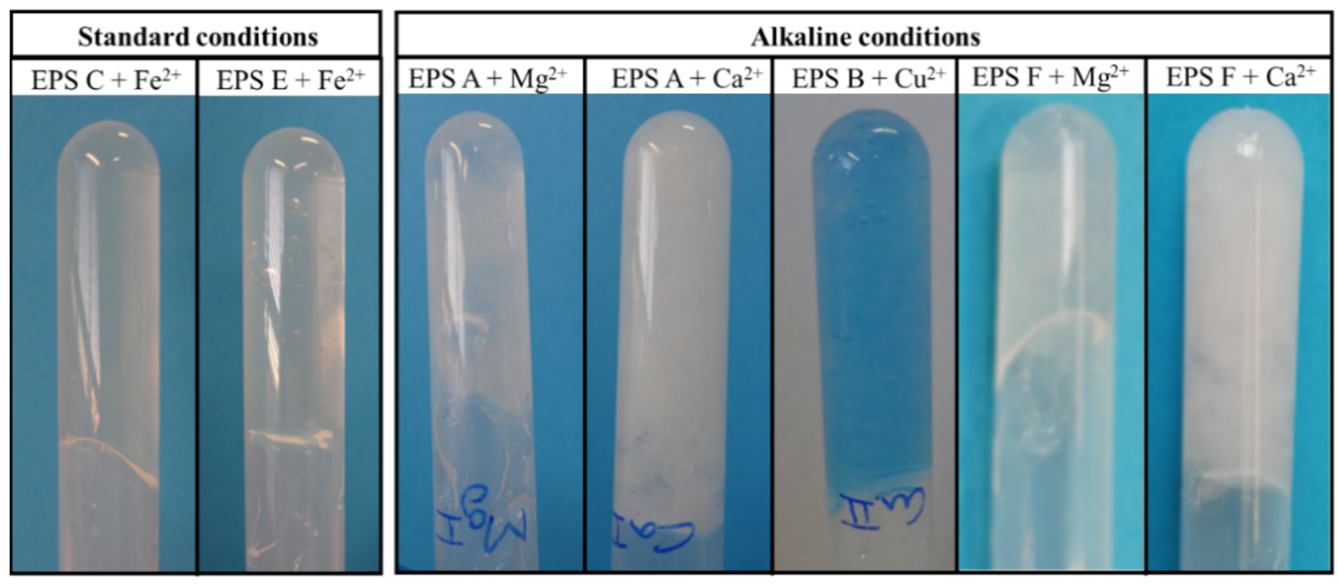

Figure 5. Results from gel formations type $(+)$ with different cations, under standard and alkaline conditions.

Overall, alkaline conditions seemed to improve gelation as five combinations originated strong gels (Table 4, Figure 5). For EPS A and F, strong gelation occurred in the presence of $\mathrm{Mg}^{2+}$ and $\mathrm{Ca}^{2+}$, and a weak gel was formed in the presence of $\mathrm{Fe}^{2+}$. In terms of their compositions, EPS A and F had high uronic acid content $(42.1$ and $37.5 \mathrm{~mol} \%$, respectively) and similar acyl compositions, namely both were rich in pyruvate and had acetate in smaller amounts (Table 2). Moreover, EPS B formed a strong gel only with $\mathrm{Cu}^{2+}$ cations (Table 4, Figure 5). EPS B is composed of Gal, GlcA, Glc, and Gal A and, compared with the other polymers, had the highest uronic acid content (45.5 mol\%) (Table 2). Similarly, the two Vibrio EPS, HE800, and MO245, formed strong gels with $\mathrm{Cu}^{2+}$, but not with other cations, such as $\mathrm{Ca}^{2+}[4,41]$. The authors suggested that these results were due to the stronger affinity of uronic acid rich polysaccharides for $\mathrm{Cu}^{2+}$ compared to $\mathrm{Ca}^{2+}[4]$, which is in accordance with our findings. The presence of cations, such as $\mathrm{Ca}^{2+}, \mathrm{Mg}^{2+}$, and $\mathrm{Cu}^{2+}$, might grant valuable biological properties to the gels, as these metals have antibacterial properties, are capable of promoting cell proliferation and differentiation, increase growth factors expression, and stimulate angiogenesis [41,42]. Thus, these cation-mediated gels might have a promising future in wound management and tissue engineering.

\section{Materials and Methods}

\subsection{Sample Collection and Bacterial Isolation}

During different sampling campaigns, samples were collected from different sources in three marine sites in French Polynesia, southern Pacific Ocean, namely, Moorea Island lagoon (Society Archipelago) Fakarava atoll (Tuamotu Archipelago), and Tikehau atoll (Tuamotu Archipelago) (Table 1). In the laboratory, immediately upon retrieval, all samples were treated according to their nature. Enrichment cultures in appropriate marine medium led to a collection of up to 2000 isolates. Around $10 \%$ of the bacterial collection was screened for the ability to secrete EPS. The isolates were plated on 2216E (Difco ${ }^{\mathrm{TM}}$, Sparks, MD, USA) [43,44] solid medium supplemented with glucose (Interchem, Auckland, new Zealand) at a concentration of $30 \mathrm{~g} \mathrm{~L}^{-1}$ and incubated at ambient temperature. The bacteria were selected based on their ability to show a mucoid phenotype (Figure 1). Six isolates belonging to Alteromonas genus were used in this study (Table 1). The strains were deposited 
at Collection Nationale de Cultures de Microorganismes (CNCM) of Pasteur Institute under the Budapest Treaty.

\subsection{EPS Production and Extraction}

EPS production was performed at $30{ }^{\circ} \mathrm{C}$ in a 1-liter fermenter (New Brunswick, Toulouse, France), containing $1 \mathrm{~L}$ of 2216 E-glucose broth. A batch of the culture medium was inoculated at $10 \%(v / v)$ with a suspension of cells in exponential growth phase. The $\mathrm{pH}$ was adjusted and maintained at 7.6 by automatic addition of $\mathrm{NaOH}$ (Tikitea, Tahiti, French Polynesia) $2 \mathrm{~mol} \mathrm{~L}^{-1}$. Foaming was avoided by addition of Pluronic-PE6100 oil (PMC Ouvrie, Carvin, France), and the agitation rate was controlled at 200-1200 rpm to maintain the dissolved oxygen concentration at $40 \%$ of the air saturation. Glucose supplementation was $6 \%\left(60 \mathrm{~g} \mathrm{~L}^{-1}\right)$ for all strains. Fermentations were stopped when glucose was consumed, between 24 up to $48 \mathrm{~h}$, according to the strain $[45,46]$. Water-soluble exopolysaccharides were recovered from the culture medium by high-speed centrifugation $(20,000 \times g$ for $2 \mathrm{~h}$, at $25^{\circ} \mathrm{C}$ ), then purified by ultrafiltration against deionized water using a pellicon-2 Mini Holder equipped with a Biomax $100 \mathrm{~K}$ filter (Millipore Corporation, Bedford, MA, USA). Supernatants were filtered on Poly Ether Sulfone (PES) before ultimate concentration and lyophilized prior to further analysis.

\subsection{EPS Characterization}

\subsubsection{EPS Composition}

The total neutral carbohydrate and uronic acid contents were determined by the method proposed by orcinol-sulfuric method $[47,48]$ and the meta-hydroxydiphenyl method [49], respectively. The molar ratio of monosaccharides was determined according to Kamerling et al. [50] and Montreuil et al. [51]. The monosaccharides were analyzed after either aqueous hydrolysis or acidic methanolysis of the polymers and subsequent GC analyses as peracetylated derivatives or trimethylsilyl derivatives, respectively. Each value is a mean of three determinations.

Protein content was quantified by a modified Lowry method, as described by Concórdio-Reis et al. [52]. For the determination of inorganic content, lyophilized EPS samples $(\sim 40 \mathrm{mg})$ were placed at $100{ }^{\circ} \mathrm{C}$ until a constant weight was attained. The dried EPS samples were subjected to pyrolysis $\left(550^{\circ} \mathrm{C}, 24 \mathrm{~h}\right.$ ), and weighted for the gravimetric quantification of the inorganic content. Acyl groups were analyzed by HPLC with an Aminex HPX-87H $300 \times 7.8 \mathrm{~mm}$ column (Biorad, Hercules, CA, USA) coupled with UV detector $(210 \mathrm{~nm})$, as described by Concórdio-Reis et al. [52]. Sulfate concentration in the hydrolysates was determined by HPLC using a Thermo Ionpac AS9-HC $250 \times 4 \mathrm{~mm}$ column and a Thermo Ionpac AG11HC column (Thermo Scientific ${ }^{\mathrm{TM}}$ Dionex $^{\mathrm{TM}}$, Sunnyvale, CA, USA), equipped with a conductivity detector. The analysis was performed at $25^{\circ} \mathrm{C}$, using sodium acetate $(8 \mathrm{mM})$ at a flow rate of $1 \mathrm{~mL} \mathrm{~min}^{-1}$. All analysis were performed in duplicate.

\subsubsection{Fourier Transform Infra-Red (FTIR) Spectroscopy}

FTIR were recorded on a Spectrum II spectrometer (Perkin-Elmer, Llantrisant, UK). The spectra were obtained between 500 and $4500 \mathrm{~cm}^{-1}$ after 10 scans, at room temperature.

\subsubsection{Molecular Mass Distribution}

The analyses were performed on a Prominence HPLC system from Shimadzu equipped with a flow refractive index detector (RID20A from Shimadzu, Kyoto, Japan), a UV detector (SPD40A from Shimadzu operating at $280 \mathrm{~nm}$ ) and a DAWN HELEOS Light Scattering detector from Wyatt, operating at 18 scattering angles and at a wavelength of $660 \mathrm{~nm}$. Separation was performed with a guard column SHODEX OH PACK SB-G-6B and two SHODEX columns OH PACK SB-806MHQ $(13 \mu \mathrm{m}, 300 \times 8 \mathrm{~mm})$ and SB-805 HQ $(7 \mu \mathrm{m}, 300 \times 8 \mathrm{~mm})$. The average molar masses (number average molar mass $\mathrm{Mn}$ and weight average molar 
mass $\mathrm{Mw})$ and the dispersity index $(\bigoplus=\mathrm{Mw} / \mathrm{Mn})$ were derived both from the RI and MALS signal using a specific refractive index increment $(\mathrm{dn} / \mathrm{dC})$ of $0.135 \mathrm{~mL} / \mathrm{g}$.

\subsubsection{Thermogravimetry (TG) Analysis}

EPS samples ( $10 \mathrm{mg})$ were characterized by Thermogravimetry (TG) using a Thermogravimetric Analyzer Labsys EVO (Setaram, Caluire, France), with a heating rate of $10{ }^{\circ} \mathrm{C} \cdot \mathrm{min}^{-1}$, from 25 to $500{ }^{\circ} \mathrm{C}$.

\subsection{EPS Functional Properties}

\subsubsection{Rheological Properties}

The apparent viscosity of the EPS aqueous solutions ( $1 w / v \%)$ was measured at $25^{\circ} \mathrm{C}$ using a controlled stress rheometer (Haake Mars III-Thermo Scientific, Karlsruhe, Germany), with a UTC-Peltier system to control temperature, and a cone-plate sensor system (angle $2^{\circ}$, diameter $35 \mathrm{~mm}$ ). Measurements were carried out using a stationary shear flow, according to an adapted method from Freitas et al. [37].

\subsubsection{Gel Forming Capacity}

The gel forming capacity of the EPS was tested by preparation of cation-mediated gels using divalent cations $\left(\mathrm{FeSO}_{4} \cdot 7 \mathrm{H}_{2} \mathrm{O}\right.$, Honeywell Fluka, Seelze, Germany, $\mathrm{CuSO}_{4} \cdot 5 \mathrm{H}_{2} \mathrm{O}$, AppliChem Panreac, Barcelona, Spain, $\mathrm{CaCl}_{2} \cdot 2 \mathrm{H}_{2} \mathrm{O}$, AppliChem Panreac, Barcelona, Spain, and $\mathrm{MgSO}_{4} \cdot 7 \mathrm{H}_{2} \mathrm{O}$, BioChem Chemopharma, Cosne sur Loire, France) and a trivalent cation ( $\mathrm{FeCl}_{3} \cdot 6 \mathrm{H}_{2} \mathrm{O}$, Alfa Aesar, ThermoFisher, Kandel, Germany). The gelation studies were performed according to the procedure described by Shimada et al. [53], with minor modifications: $5 \mathrm{~mL}$ of EPS solution $\left(5 \mathrm{~g} \mathrm{~L}^{-1}\right)$ was added to the metal salt $(10 \mathrm{mg}$ of cation) and agitated until dissolution and gel formation was assessed (standard conditions). Afterwards, $1 \mathrm{~mL}$ of $\mathrm{NaOH}(2 \mathrm{M})$ was added and the solution was agitated to test gelation in alkaline conditions. Gel formation was assessed by visual inspection, and the gels were categorized according to their strength and homogeneity: $(+)$ for homogeneous gels that maintained their gel structure in a tube-inversion test, (-) for homogeneous gels that did not sustain their structure in the inversion test, and (-) for small non-homogeneous gels.

\section{Conclusions}

The exopolysaccharides from six Alteromonas strains collected from French Polynesia marine environments were characterized and investigated for their functional properties. The Alteromonas strains produced high molecular weight heteropolysaccharides, with high contents in uronic acids and rare sugars in their composition. These monomers, together with the sulfate groups also detected in their composition, indicate that these EPS could have interesting biological properties that are worthy to explore. Moreover, the EPS showed a good thermal stability, interesting rheological properties, and gel forming capacity, envisaging their potential to be used as structuring or thickening agents in wound management, tissue engineering, drug delivery, food products, cosmetic formulations, and oil drilling fluids.

Author Contributions: Conceptualization, P.C.-R., J.G., and F.F.; Formal analysis, P.C.-R., V.D.A., X.M., and J.G.; Funding acquisition, F.F. and M.A.M.R.; Investigation, P.C.-R. and X.M.; Methodology, P.C.-R. and V.D.A.; Supervision, F.F. and M.A.M.R.; Writing—original draft, P.C.-R.; Writing-review and editing, J.G., F.F., and M.A.M.R. All authors have read and agreed to the published version of the manuscript.

Funding: This work was financed by national funds from FCT-Fundação para a Ciência e a Tecnologia, I.P., in the scope of the projects UIDP/04378/2020 and UIDB/04378/2020 of the Research Unit on Applied Molecular Biosciences-UCIBIO, LA/P/0140/2020 of the Associate Laboratory Institute for Health and Bioeconomy-i4HB, and UIDP/04129/2020 and UIDB/04129/2020 of the Research Center Linking Landscape, Environment, Agriculture and Food-LEAF. Patrícia Concórdio-Reis acknowledges FCT/MCTES for PhD grant SFRH/BD/131947/2017. 
Institutional Review Board Statement: Not applicable.

Informed Consent Statement: Not applicable.

Data Availability Statement: The data presented in this study are available on request from the corresponding author. The data are not publicly available due as public availability violates the consent given by the study participants.

Conflicts of Interest: The authors declare no conflict of interest.

\section{Appendix A}

Examples of the two distinctive HPSEC results, one and two chromatographic peaks, obtained from molecular mass distribution determination (Figure A1).

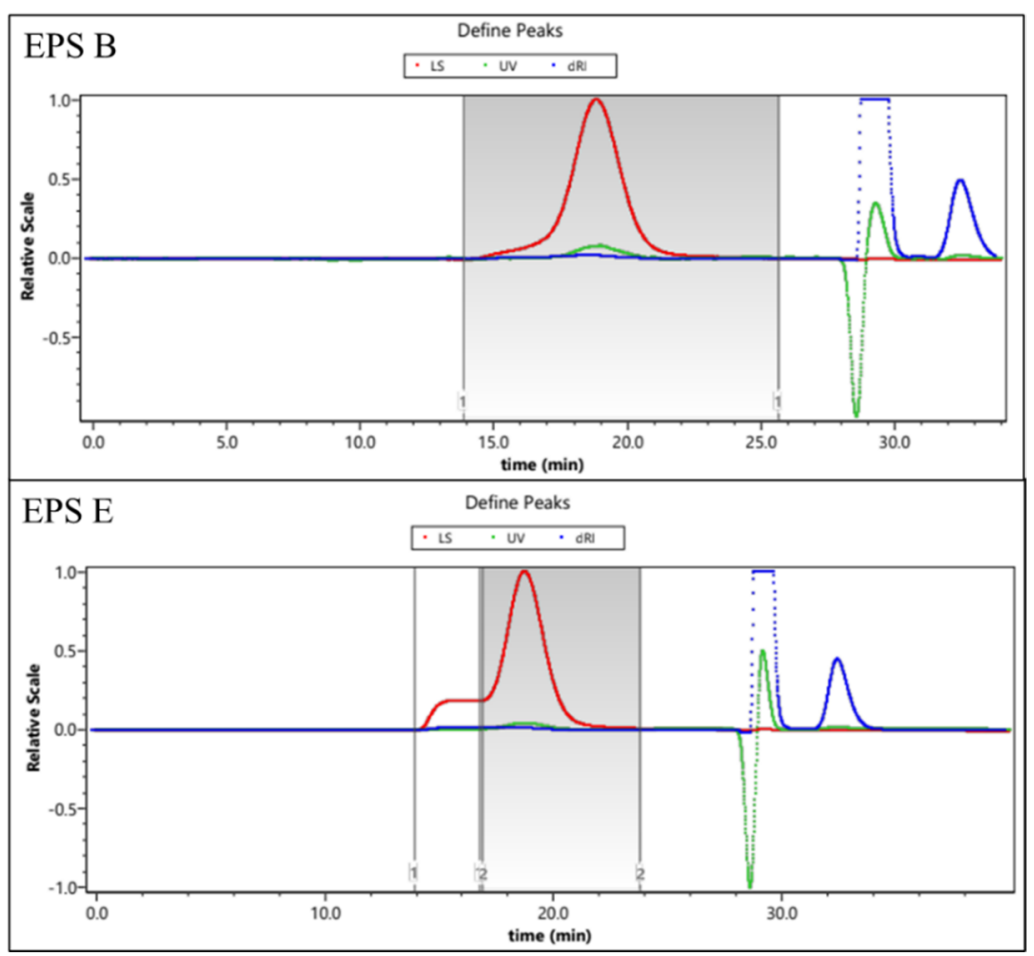

Figure A1. Molecular weight determination of EPS B and EPS E.

\section{Appendix B}

Thermal degradation steps of the EPS (Table A1).

Table A1. Thermal degradation steps of the EPS produced by Alteromonas strains isolated from French Polynesia.

\begin{tabular}{ccc}
\hline EPS & Temperature $\left({ }^{\circ} \mathbf{C}\right)$ & Weight Loss (\%) \\
\hline \multirow{2}{*}{ A } & $40.20-192.81$ & 14.6 \\
& $193.18-405.15$ & 42.5 \\
\hline \multirow{2}{*}{ B } & $40.59-186.14$ & 13.8 \\
& $186.33-418.89$ & 36.4 \\
\hline \multirow{2}{*}{ C } & $37.97-189.07$ & 14.2 \\
& $189.47-428.81$ & 30.2 \\
\hline \multirow{2}{*}{ D } & $38.6-183.88$ & 12.7 \\
& $184.46-385.68$ & 45.1 \\
\hline
\end{tabular}


Table A1. Cont.

\begin{tabular}{ccc}
\hline EPS & Temperature $\left({ }^{\circ} \mathbf{C}\right)$ & Weight Loss (\%) \\
\hline \multirow{2}{*}{ E } & $36.61-188.77$ & 17.5 \\
& $189.49-390.41$ & 44.8 \\
\hline \multirow{2}{*}{ F } & $45.14-73.09$ & 12.1 \\
& $212.40-385.88$ & 41.5 \\
\hline
\end{tabular}

\section{Appendix C}

Images of gels homogeneous gels that did not sustain their structure in the inversion test (-), and small non-homogeneous gels (-) (Figure A2).

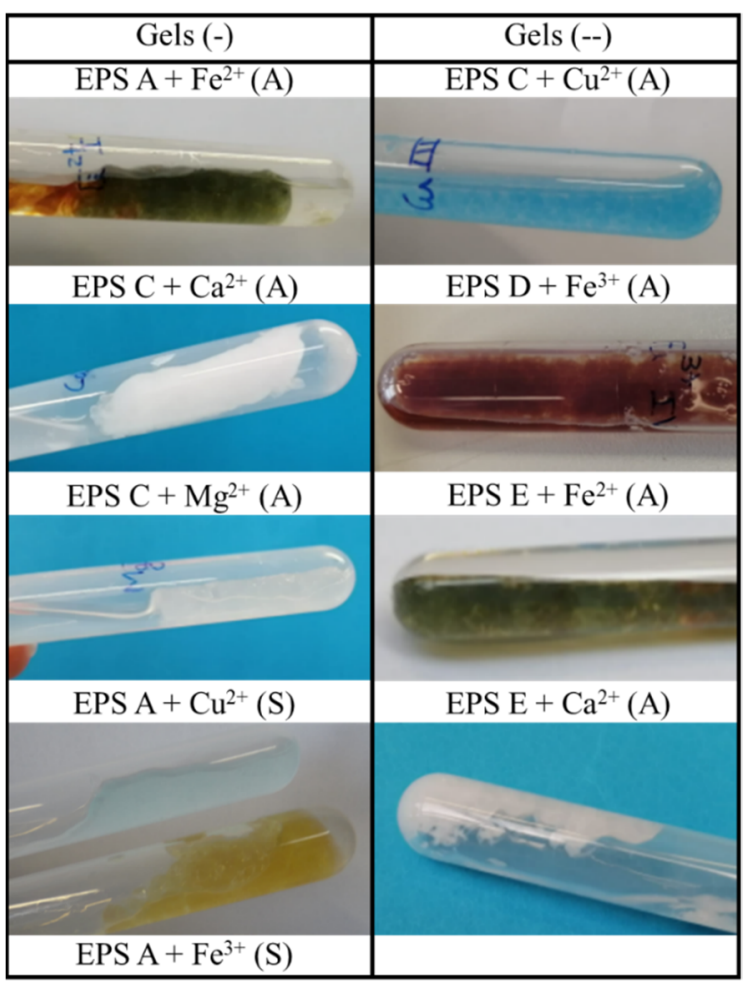

Figure A2. Results from gel formations type (-) and (-) with different cations under standard and alkaline conditions.

\section{References}

1. Roca, C.; Lehmann, M.; Torres, C.A.V.; Baptista, S.; Gaudêncio, S.P.; Freitas, F.; Reis, M.A.M. Exopolysaccharide Production by a Marine Pseudoalteromonas Sp. Strain Isolated from Madeira Archipelago Ocean Sediments. New Biotechnol. 2016, 33, 460-466. [CrossRef] [PubMed]

2. Casillo, A.; Lanzetta, R.; Parrilli, M.; Corsaro, M.M. Exopolysaccharides from Marine and Marine Extremophilic Bacteria: Structures, Properties, Ecological Roles and Applications. Mar. Drugs 2018, 16, 69. [CrossRef] [PubMed]

3. Chalkiadakis, E.; Dufourcq, R.; Schmitt, S.; Brandily, C.; Kervarec, N.; Coatanea, D.; Amir, H.; Loubersac, L.; Chanteau, S.; Guezennec, J.; et al. Partial Characterization of an Exopolysaccharide Secreted by a Marine Bacterium, Vibrio Neocaledonicus Sp. Nov., from New Caledonia. J. Appl. Microbiol. 2013, 114, 1702-1712. [CrossRef] [PubMed]

4. Martin-Pastor, M.; Ferreira, A.S.; Moppert, X.; Nunes, C.; Coimbra, M.A.; Reis, R.L.; Guezennec, J.; Novoa-Carballal, R. Structure, Rheology, and Copper-Complexation of a Hyaluronan-like Exopolysaccharide from Vibrio. Carbohydr. Polym. 2019, 222, 114999. [CrossRef]

5. Guezennec, J. Deep-Sea Hydrothermal Vents: A New Source of Innovative Bacterial Exopolysaccharides of Biotechnological Interest? J. Ind. Microbiol. Biotechnol. 2002, 29, 204-208. [CrossRef] 
6. Delbarre-Ladrat, C.; Salas, M.L.; Sinquin, C.; Zykwinska, A.; Colliec-Jouault, S. Bioprospecting for Exopolysaccharides from Deep-Sea Hydrothermal Vent Bacteria: Relationship between Bacterial Diversity and Chemical Diversity. Microorganisms 2017, 5, 63. [CrossRef]

7. Nichols, C.M.; Lardière, S.G.; Bowman, J.P.; Nichols, P.D.; Gibson, J.A.E.; Guézennec, J. Chemical Characterization of Exopolysaccharides from Antarctic Marine Bacteria. Microb. Ecol. 2005, 49, 578-589. [CrossRef]

8. Donot, F.; Fontana, A.; Baccou, J.C.; Schorr-Galindo, S. Microbial Exopolysaccharides: Main Examples of Synthesis, Excretion, Genetics and Extraction. Carbohydr. Polym. 2012, 87, 951-962. [CrossRef]

9. More, T.T.; Yadav, J.S.S.; Yan, S.; Tyagi, R.D.; Surampalli, R.Y. Extracellular Polymeric Substances of Bacteria and Their Potential Environmental Applications. J. Environ. Manag. 2014, 144, 1-25. [CrossRef]

10. Wang, J.; Salem, D.R.; Sani, R.K. Extremophilic Exopolysaccharides: A Review and New Perspectives on Engineering Strategies and Applications. Carbohydr. Polym. 2019, 205, 8-26. [CrossRef]

11. Zhang, Z.; Cai, R.; Zhang, W.; Fu, Y.; Jiao, N. A Novel Exopolysaccharide with Metal Adsorption Capacity Produced by a Marine Bacterium Alteromonas sp. JL2810. Mar. Drugs 2017, 15, 175. [CrossRef] [PubMed]

12. Freitas, F.; Torres, C.A.V.; Reis, M.A.M. Engineering Aspects of Microbial Exopolysaccharide Production. Bioresour. Technol. 2017, 245, 1674-1683. [CrossRef] [PubMed]

13. Sahana, T.G.; Rekha, P.D. A Bioactive Exopolysaccharide from Marine Bacteria Alteromonas sp. PRIM-28 and Its Role in Cell Proliferation and Wound Healing in Vitro. Int. J. Biol. Macromol. 2019, 131, 10-18. [CrossRef]

14. Zarandona, I.; Estupiñán, M.; Pérez, C.; Alonso-Sáez, L.; Guerrero, P.; de la Caba, K. Chitosan Films Incorporated with Exopolysaccharides from Deep Seawater Alteromonas sp. Mar. Drugs 2020, 18, 447. [CrossRef]

15. Nichols, C.A.M.; Guezennec, J.; Bowman, J.P. Bacterial Exopolysaccharides from Extreme Marine Environments with Special Consideration of the Southern Ocean, Sea Ice, and Deep-Sea Hydrothermal Vents: A Review. Mar. Biotechnol. 2005, 7, 253-271. [CrossRef] [PubMed]

16. Guézennec, J.; Moppert, X.; Raguénès, G.; Richert, L.; Costa, B.; Simon-Colin, C. Microbial Mats in French Polynesia and Their Biotechnological Applications. Process. Biochem. 2011, 46, 16-22. [CrossRef]

17. Zykwinska, A.; Berre, L.T.-L.; Sinquin, C.; Ropartz, D.; Rogniaux, H.; Colliec-Jouault, S.; Delbarre-Ladrat, C. Enzymatic Depolymerization of the GY785 Exopolysaccharide Produced by the Deep-Sea Hydrothermal Bacterium Alteromonas infernus: Structural Study and Enzyme Activity Assessment. Carbohydr. Polym. 2018, 188, 101-107. [CrossRef]

18. Loaëc, M.; Olier, R.; Guezennec, J. Chelating Properties of Bacterial Exopolysaccharides from Deep-Sea Hydrothermal Vents. Carbohydr. Polym. 1998, 35, 65-70. [CrossRef]

19. Mata, J.A.; Bjar, V.; Bressollier, P.; Tallon, R.; Urdaci, M.C.; Quesada, E.; Llamas, I. Characterization of Exopolysaccharides Produced by Three Moderately Halophilic Bacteria Belonging to the Family Alteromonadaceae. J. Appl. Microbiol. 2008, 105, 521-528. [CrossRef]

20. Torres, M.; Hong, K.-W.; Chong, T.-M.; Reina, J.C.; Chan, K.-G.; Dessaux, Y.; Llamas, I. Genomic Analyses of Two Alteromonas stellipolaris Strains Reveal Traits with Potential Biotechnological Applications. Sci. Rep. 2019, 9, 1-14. [CrossRef]

21. Le Costaouëc, T.; Cérantola, S.; Ropartz, D.; Ratiskol, J.; Sinquin, C.; Colliec-Jouault, S.; Boisset, C. Structural Data on a Bacterial Exopolysaccharide Produced by a Deep-Sea Alteromonas macleodii Strain. Carbohydr. Polym. 2012, 90, 49-59. [CrossRef]

22. Roca, C.; Alves, V.D.; Freitas, F.; Reis, M.A.M. Exopolysaccharides Enriched in Rare Sugars: Bacterial Sources, Production, and Applications. Front. Microbiol. 2015, 6, 288. [CrossRef]

23. de Jesus Raposo, M.; de Morais, A.; de Morais, R. Marine Polysaccharides from Algae with Potential Biomedical Applications. Mar. Drugs 2015, 13, 2967-3028. [CrossRef]

24. Liu, L.; Pohnert, G.; Wei, D. Extracellular Metabolites from Industrial Microalgae and Their Biotechnological Potential. Mar. Drugs 2016, 14, 191. [CrossRef] [PubMed]

25. Xiao, R.; Zheng, Y. Overview of Microalgal Extracellular Polymeric Substances (EPS) and Their Applications. Biotechnol. Adv. 2016, 34, 1225-1244. [CrossRef]

26. Singh, S.; Kant, C.; Yadav, R.K.; Reddy, Y.P.; Abraham, G. Cyanobacterial Exopolysaccharides: Composition, Biosynthesis, and Biotechnological Applications. In Cyanobacteria; Elsevier: London, UK, 2019; pp. 347-358. ISBN 978-0-12-814667-5.

27. Raguénès, G.; Cambon-Bonavita, M.A.; Lohier, J.F.; Boisset, C.; Guezennec, J. A Novel, Highly Viscous Polysaccharide Excreted by an Alteromonas Isolated from a Deep-Sea Hydrothermal Vent Shrimp. Curr. Microbiol. 2003, 46, 448-452. [CrossRef] [PubMed]

28. Concórdio-Reis, P.; Pereira, C.V.; Batista, M.P.; Sevrin, C.; Grandfils, C.; Marques, A.C.; Fortunato, E.; Gaspar, F.B.; Matias, A.A.; Freitas, F.; et al. Silver Nanocomposites Based on the Bacterial Fucose-Rich Polysaccharide Secreted by Enterobacter A47 for Wound Dressing Applications: Synthesis, Characterization and in Vitro Bioactivity. Int. J. Biol. Macromol. 2020, 163, 959-969. [CrossRef] [PubMed]

29. Chen, X.; Song, L.; Wang, H.; Liu, S.; Yu, H.; Wang, X.; Li, R.; Liu, T.; Li, P. Partial Characterization, the Immune Modulation and Anticancer Activities of Sulfated Polysaccharides from Filamentous Microalgae Tribonema sp. Molecules 2019, 24, 322. [CrossRef]

30. Liu, X.; Zhang, M.; Liu, H.; Zhou, A.; Cao, Y.; Liu, X. Preliminary Characterization of the Structure and Immunostimulatory and Anti-Aging Properties of the Polysaccharide Fraction of Haematococcus pluvialis. RSC Adv. 2018, 8, 9243-9252. [CrossRef]

31. Trabelsi, L.; Chaieb, O.; Mnari, A.; Abid-Essafi, S.; Aleya, L. Partial Characterization and Antioxidant and Antiproliferative Activities of the Aqueous Extracellular Polysaccharides from the Thermophilic Microalgae Graesiella sp. BMC Complement. Altern. Med. 2016, 16, 1-10. [CrossRef] 
32. Insulkar, P.; Kerkar, S.; Lele, S.S. Purification and Structural-Functional Characterization of an Exopolysaccharide from Bacillus licheniformis PASS26 with in-Vitro Antitumor and Wound Healing Activities. Int. J. Biol. Macromol. 2018, 120, 1441-1450. [CrossRef]

33. Rütering, M.; Schmid, J.; Gansbiller, M.; Braun, A.; Kleinen, J.; Schilling, M.; Sieber, V. Rheological Characterization of the Exopolysaccharide Paenan in Surfactant Systems. Carbohydr. Polym. 2018, 181, 719-726. [CrossRef]

34. Ji, S.; Li, H.; Wang, G.; Lu, T.; Ma, W.; Wang, J.; Zhu, H.; Xu, H. Rheological Behaviors of a Novel Exopolysaccharide Produced by Sphingomonas WG and the Potential Application in Enhanced Oil Recovery. Int. J. Biol. Macromol. 2020, 162, 1816-1824. [CrossRef]

35. Cruz, M.; Freitas, F.; Torres, C.A.V.; Reis, M.A.M.; Alves, V.D. Influence of Temperature on the Rheological Behavior of a New Fucose-Containing Bacterial Exopolysaccharide. Int. J. Biol. Macromol. 2011, 48, 695-699. [CrossRef]

36. Alves, V.D.; Freitas, F.; Costa, N.; Carvalheira, M.; Oliveira, R.; Gonçalves, M.P.; Reis, M.A.M. Effect of Temperature on the Dynamic and Steady-Shear Rheology of a New Microbial Extracellular Polysaccharide Produced from Glycerol Byproduct. Carbohydr. Polym. 2010, 79, 981-988. [CrossRef]

37. Freitas, F.; Alves, V.D.; Torres, C.A.V.; Cruz, M.; Sousa, I.; Melo, M.J.; Ramos, A.M.; Reis, M.A.M. Fucose-Containing Exopolysaccharide Produced by the Newly Isolated Enterobacter Strain A47 DSM 23139. Carbohydr. Polym. 2011, 83, 159-165. [CrossRef]

38. Carreau, P.J. Rheological Equations from Molecular Network Theories. J. Rheol. 1972, 16, 99-127. [CrossRef]

39. Torres, C.A.V.; Ferreira, A.R.V.; Freitas, F.; Reis, M.A.M.; Coelhoso, I.; Sousa, I.; Alves, V.D. Rheological Studies of the Fucose-Rich Exopolysaccharide FucoPol. Int. J. Biol. Macromol. 2015, 79, 611-617. [CrossRef] [PubMed]

40. $\mathrm{Hu}, \mathrm{H} . ; \mathrm{Xu}$, F.-J. Rational Design and Latest Advances of Polysaccharide-Based Hydrogels for Wound Healing. Biomater. Sci. 2020, 8, 2084-2101. [CrossRef]

41. Zykwinska, A.; Marquis, M.; Sinquin, C.; Cuenot, S.; Colliec-Jouault, S. Assembly of HE800 Exopolysaccharide Produced by a Deep-Sea Hydrothermal Bacterium into Microgels for Protein Delivery Applications. Carbohydr. Polym. 2016, 142, 213-221. [CrossRef] [PubMed]

42. Hoppe, A.; Güldal, N.S.; Boccaccini, A.R. A Review of the Biological Response to Ionic Dissolution Products from Bioactive Glasses and Glass-Ceramics. Biomaterials 2011, 32, 2757-2774. [CrossRef]

43. Zobell, C.E. Studies on Marine Bacteria. I. The Cultural Requirements of Heterotrophic Aerobes. J. Mar. Res. 1941, 4, 42-75.

44. Oppenheimer, C.H.; Zobell, C.E. The Growth and Viability of Sixty-Three Species of Marine Bacteria as Influenced by Hydrostatic Pressure. J. Mar. Res. 1952, 11, 10-18.

45. Raguenes, G.; Pignet, P.; Gauthier, G.; Peres, A.; Christen, R.; Rougeaux, H.; Barbier, G.; Guezennec, J. Description of a New Polymer-Secreting Bacterium from a Deep-Sea Hydrothermal Vent, Alteromonas macleodii Subsp. fijiensis, and Preliminary Characterization of the Polymer. Appl. Environ. Microbiol. 1996, 62, 67-73. [CrossRef] [PubMed]

46. Cambon-Bonavita, M.-A.; Raguenes, G.; Jean, J.; Vincent, P.; Guezennec, J. A Novel Polymer Produced by a Bacterium Isolated from a Deep-Sea Hydrothermal Vent Polychaete Annelid. J. Appl. Microbiol. 2002, 93, 310-315. [CrossRef]

47. Tilmans, J.; Philippi, J. Uber Den Gehalt Der Wichtigsten Protein Der Nahrangsmittel an Kohlehydrat Andu“ber Ein Kolorimetriches Verfharen Zur Quantitativen Beshimmung von Stucksoffreiem Zucker in Elweiss. Biochim. Ztg. 1929, $215,36-60$.

48. Rimington, C. The Carbohydrate Complex of Serum Protein II: Improved Method for Isolation and Determination of Structure. Isolation of Glucosaminodimannose from Protein of Blood. Biochem. J. 1931, 25, 1062-1071. [CrossRef] [PubMed]

49. Blumenkrantz, N.; Asboe-Hansen, G. New Method for Quantitative Determination of Uronic Acid. Anal. Biochem. 1973, 54, 484-489. [CrossRef]

50. Kamerling, J.P.; Gerwig, G.J.; Vliegenhart, J.F.G.; Clamp, J.R. Characterization by Gas Chromatography-Mass Spectrometry of Pertrimethylsilyl Glycosides Obtained in the Methanolysis of Glycoproteins and Glycolipids. Biochem. J. 1975, 151, 491-495. [CrossRef]

51. Montreuil, J.; Bouquelet, S.; Debray, H.; Fournet, B.; Spik, G.; Strecker, G. Glycoproteins. In Carbohydrate Analysis: A Practical Approach; IRL Press: Washington, DC, USA, 1986; pp. 143-204.

52. Concórdio-Reis, P.; Reis, M.A.M.; Freitas, F. Biosorption of Heavy Metals by the Bacterial Exopolysaccharide FucoPol. Appl. Sci. 2020, 10, 6708. [CrossRef]

53. Shimada, A.; Nakata, H.; Nakamura, I. Acidic Exopolysaccharide Produced by Enterobacter sp. J. Ferment. Bioeng. 1997, 84, 113-118. [CrossRef] 